\title{
TRUE AND FAIR VIEW AND CREATIVE ACCOUNTING CONCEPTUAL DELIMITATIONS BASED ON PAPINEAU`S TREE METHODOLOGY
}

\author{
Alina Beattrice Vladu ${ }^{1} *$ \\ Dumitru Matiş ${ }^{2}$ \\ Oriol Amat Salas ${ }^{3}$
}

\begin{abstract}
Our theoretical research was developed based on Papineau's methodology in order to be able to develop a comprehensive framework by constructing an internal history of the literature. By using this particular approach the main body of the literature is summarized conducting in the end to a rigorous and comprehensive understanding of it with fruitful implications. Both true and fair view and creative accounting are dynamic concepts that comprised various debates in the literature regarding to their conceptual delimitations and definition. One implication of our study is related to the elaboration of definitions for true and fair view and further terminology assessment for creative accounting, based on the main findings reflected by conducting Papineau's methodology. Other implication can be related to the internal construction history of the literature and presenting the primary core terms comprised in the area of research of true and fair view and creative accounting.
\end{abstract}

Key words: true and fair view, creative accounting, Papineau's tree methodology

JEL codes: M41

\section{Introduction}

Papineau's Tree (1979) is an efficient approach that relies on the creation of a network of core terms for the area of research in question and is designed to represent the theoretical development within a particular research programme (Ryan et al., 1992:152). The methodology helps in demarcate those terms which are central to all researchers in an area and those at other extreme which are shared only by a small number of researchers (Ryan et al., 1992:152). Based on this methodology a relevant framework can be developed and more than that the methodology can be useful in the identification of the main consensus expressed in the literature.

Most statements regarding true and fair view principle concentrate almost exclusively on its implication rather than its definition or conceptual delimitation. Even if it provides "the ultimate foundation for financial reporting" (Leach, 1981:7) and despite the significant role played in accounting, auditing and reporting, the concept has attracted much controversy and debate regarding its meaning.

Walton (1993) summarizes the essence of the concept as following: "The theory and practice of financial accounting are full of odd notions, curious inconsistencies and improbable ways of approaching problems, but surely the single most bizarre notion is the British True and Fair View".

1 Babes-Bolyai University, Faculty of Economics and Business Administration, e-mail: beattrice.vladu@econ.ubbcluj.ro

${ }^{2}$ Babes-Bolyai University, Faculty of Economics and Business Administration, e-mail: dumitru.matis@econ.ubbcluj.ro

${ }^{3}$ Universitat Pompeu Fabra, e-mail: oriol.amat@upf.edu 
The various definitions of creative accounting, earnings management, income smoothing was inconsistent in the literature. Major problems with those definitions include ambiguity and immeasurability.

This part of the research is motivated by the fact that the literature has revealed an inconsistency in the definitions of all the above.

Ambiguity is not the only feature of these definitions but also the aura of relativity since the details of what comprises creative accounting mechanism for instance haven't reached a consensus in the literature as McBarnet and Whelan (1999) asserted: "One person's creative accounting is another's carefully considered judgment; one person's device to deceive is another's legitimate management tool; one person's systematic understatement of profits is another's application of the prudence concept" (1999:6;99).

In order to be able to reduce the aura of ambiguity that accompanies this research area we reviewed the conceptual delimitations of all concepts mentioned above and portrait the conceptual distinctions and similarities of all of them. Based on the fact that we work with a theoretical framework adjudicated in international research, the manner to discuss upon the verification of our work is simple and transparent. The review of the literature provides evidence of the validity regarding the developed definitions. The results are important for both theoretical and empirical researches on creative accounting, earnings management, income smoothing as well as for regulators, lawmakers, firms and investors.

Connected to the above mentioned, True and Fair View and creative accounting are important items that need to be assessed.

\section{Theoretical framework for sustaining our research question}

Approaching the meaning of the True and Fair View concept, Walton (1993) suggested that this particular item should be treated according to Saussure (1919) conceits, who in his book Cours de Linguistique Generale (translated as Course in General Linguistics) distinguished between the signifier and signified of a certain word. If we where to transfer this approach in accounting we can conclude that the signifiers of the concept are the words "give a True and Fair View", whereas the signified is the main underlying idea. Based on the fact that the concept comprises several different meanings, the latter approach is useful in order to identify those meanings.

Sir Russell Kettle (1948), cited by Cowan (1965), set the pattern regarding what True and Fair View might mean or what its implications might be, by the following: "A True and Fair View implies that all statutory and other essential information is not only available but is presented in a form in which it can be properly and readily appreciated".

Lee G.A. (1981), cited by Rutherford (1985) in The True and Fair View Doctrine: A Search for Explanation, suggested a definition for the concept of True and Fair View as: "it is generally understood to mean a presentation of accounts, drawn up according to accepted accounting principles, using accurate figures as far as possible, and reasonable estimates otherwise; and arranging them to show, within the limits of current accounting practice, as objective a picture as possible, free from willful bias, distortion, manipulation, or concealment of material facts".

Lee T.A. (1982), cited also by Rutherford (1985) in The True and Fair View Doctrine: A Search for Explanation, elaborated a comprehensive definition regarding True and Fair View explaining what can be understood through each one of its individual components, as:"True means that the accounting information contained in the financial statements has been quantified and communicated in such a way as to correspond to the economic events, activities and transactions it is intended to describe . . . Fair means that the accounting information has been measured and disclosed in a manner which is objective and without prejudice to any particular sectional interests in the company".

Lee T.A. (1982) defined both individual components of the True and Fair View construction supposing that both truth and fairness are susceptible to vary according to time and place becoming 
relative to the framework within which they reside. Its attempt to define the concept by expressing meanings to each component may be more useful in defining it in contrast with the demarche of defining the concept as an ensemble.

Rutherford (1985) was one the pioneers that stated that this wording lacks a widely accepted definition and that the Companies Act Law from United Kingdom and accounting standards who didn't define it fail to gave "content" to this particular concept having the fact that both of them "explicitly require that their specifications of accounting principles should be abandoned where this is necessary to achieve True and Fair View" (Rutherford, 1985). He associated the True and Fair View with the wording "accurate" and "correct" and also with "full and proper disclosure" and stated that "the profession should regard TFV as having a technical meaning, to be determined within the accounting arena itself and not derived from legal sources or ordinary meanings" (Rutherford, 1985). Referring to what True and Fair View should mean, Nobes and Parker (1991a) characterized it by "not misleading".

Fowle (1992) defines the principle through "absence of material error". Alexander (1993) examined the meaning of the True and Fair View concept requirement and meaning in different translations in United Kingdom, France and Germany and concluded that there is no certainty that it means the same thing. Hudack and Orsini (1993) conducted o similar study and reached to similar conclusions. That True and Fair View may mean different things in different countries has been noted also by Nobes (1993).

Burlaud (1993) refers to True and Fair View as the recipient of the accounts that should not be led by the preparer, even involuntarily, into making an error. He poses the fact that "the concept of the True and Fair View is above all a guide for standard setters in Europe - and rarely one for business".

Walton (1993) considers for the meanings of True and Fair View one of the following three directions: 1.) A legal residual clause that operates as a safety net put able to be invoked in unusual circumstances. If True and Fair View is considered to be a legal residuary, it will probably have little practical individual meaning; 2.) An independent concept defined independently of accounting rules and representing the higher objective to be sought by accountants; 3.)Code expression for generally accepted accounting principles. In his opinion the meanings attributed to the concept of True and Fair View given in financial statements is related to the fact that they should be drawn up under currently accepted practice. If this concept is considered to encapsulate the generally accepted accounting principles then it may be utilized in order to deal with "accounting problems caused by the open areas and ambiguities" found in the accounting law (Ordelheide, 1993).

Jones (1994) stated that the concept of True and Fair View may prove difficult for even the "most eminent and skilled accountants to define", while Parker and Nobes (1994: xiii) concluded that the True and Fair View is both "overriding and undefined" but in the same time a central but mysterious feature of financial reporting".

Regarding the definition of this concept the opinions traced are unanimous and sustain the fact that this principle is an undefined one. This aspect is underlined by Ordelheide (1996) also who stated that "...even in the UK the True and Fair View concept is nearer to a black box than to a well defined objective of accounts". The author pointed out further the fact that by developing a clear concept of the True and Fair View generally, conflicts may arise between this principle and several specific provisions of the Fourth Directive settled before the concept was defined.

As we stated before, the concept seams to suffer from lack of a common accepted definition and only features of its content are characterized. Summarizing the opinions expressed in the literature by the above authors and others we can conclude that most of them give the True and Fair View a general interpretation and that particular interpretation is related to compliance with accounting rules and principles. Studies conducted by Cowan (1965); Edey (1971); Hoffman and Arden (1983); Pound (1985); Rutherford (1985); Radcliffe (1990); Walton (1993); Gearin and 
Khandelwal (1995); Nobes and Parker (1991b); Parker and Nobes (1991) and Deegan et al. (1994) sustain this point of view.

Chambers and Wolnizer (1991) offers an explanation: "there is no warrant for supposing that the terms 'true and correct' or 'true and fair' once had, or now have, any meaning other than the plain and natural meanings of their components..." and their argument may consist a explanation for the fact that this concept was not defined.

Karan (2002:50) stated that the utterance regarding financial statement "not misleading by reason of material statements or omissions" it is more meaningful than the utterance regarding financial statement that must give "True and Fair View".

Offering an operational definition of True and Fair View, McEnroe and Martens (2004) stated that True and Fair View requirement must interpreted to mean that: "...all material transactions have been recorded in a manner in which their form is equal to their substance", and the fact that this notion "is also applied to the financial statements in the aggregate".

Following a similar path and approaching this time creative accounting concept we can assert that the main idea that underlie this area of research split the opinions of scholars in two: some that regards it from a positive point of view and some that consider that creative accounting comprises only negative items. Discussing about the first delimitation, we can find if we summarize the main body of the literature, as a leitmotif the words: "creation" or "innovation". Both concepts are of course related to positive changes in economic, social and political environments. The negative optics comprises undesirable practices that assimilates items that are highly unethical, deceptive and misleading.

Creative accounting as a concept is included in accounts manipulation area, treated in the research area as a complex segment of terminologies that included not only creative accounting but also its constituents. We truly believe that there is no other field in accounting research as slippery as creative accounting research, no other that brings together so much contradiction.

An example of terminology contradiction between European and American point of views is related to creative accounting areas of manifestation. In this respect Charles Mulford and Eugene Comiskey (2002) include in creative accounting areas of manifestation income smoothing (labeled as a form of earnings management) and that Stolowy and Breton in their article A Framework for the Classification of Accounts Manipulation (2004) stated the fact that creative accounting "mainly includes earnings management (without any reference to income smoothing)" (2004). The latter also admit the fact that: „Creative accounting has been used with various meanings and brings some confusion into the field of accounts manipulation" (2004).

When discussing regarding the practice of creative accounting, we can assert that this demarche comprises mainly items that has the power to distort the underlying financial performance of a firm with the specific scope of misleading the investors or financial analysts when assessing the performance of the firm and further compare between different companies.

Metcalf (1977) approaching the concept of creative accounting asserts that this practice is used to "describe accepted accounting techniques which permit corporations to report financial results that may not accurately portray the substance of their business activities ... creative accounting is recognized as a synonym for deceptive accounting" (1977:188).

Michael Jameson in his book A Practical Guide to Creative Accounting, posit the fact that the major part of creative accounting area is reflected by income smoothing. The author asserted the fact that: "Creative accountants might also argue that, in the long run, their activities are limited to income smoothing since many creative accounting techniques rebound fairly quickly" (1988:21). Naser (1993) in his book Creative financial accounting: its nature and use, elaborated an definition for what creative accounting can mean, as the following: "Creative accounting is the transformation of financial accounting figures from what they actually are to what preparers desire by taking advantage of the existing rules and/or ignoring some or all of them" (1993:2). 
Amat and Gowthorpe (2004) regard creative accounting as the use of accounting to mislead rather than help the intended user, deliberately taking advantage of areas where there are ambiguities and discontinuities. In their article Creative Accounting: Some Ethical Issues of Macroand Micro-Manipulation published in 2005, the authors defined creative accounting as a demarche that has the scope of creating "the view of reality that they wish to have communicated to users of the financial statements".

Vladu and Matiş (2010) defines creative accounting as a mean being used by companies in order to adapt, develop and become more competitive in the turbulent environments in which they operate, adaptation that requires highly adaptive professionals able to generate creative ideas even if these employ interpreting grey areas to their advantage, being less prudent almost all the time; seek for loopholes in specific rules or develop devices which regulators have not thought to forbid.

Based on the relevant theoretical framework, we developed the research question as following:

- By constructing an internal history of accounting based on Papineau's methodology, we can be able to assess better the conceptual delimitations comprised in the area of research?

\section{Methodology}

Since our research is not an empirical one, but a fundamental research we were interested to chose a proper methodology that further can serve our purposes. Since the main scope was to construct an internal history of the literature we were further interested to comprise in our research an adequate methodology. Based on the fact that the proposed methodology wasn't applied earlier in our area of research and based on its advantages as Ryan et al., (1992:152-153) asserted, Papineau`s tree was used.

As implicit methodology adopted it was the inductive methodology that sustain the main idea of the fact that general conclusions regarding the development of a subject are drawn based on a sample of literature.

\section{concepts}

Findings - Discussions based on relevant opinions that emphasize the approached

When approaching a new area of research the process of reviewing the literature is considered the first attempt employed in order to "backtrack" the studies and views that are considered to be representative for that particular area. All the studies are conducted and developed by researchers that activate in the boundaries of that area. Mainly the reviewing of the literature after "discovering" is considered to be realized and every one of the authors cited appear in one particular study together with the opinions, views and results of the study.

We wanted to follow a different approach and identify not only the authors but mostly to let their work "speak" for them in this large area of interest. In this respect we identified the main themes and issues of concern by sampling the literature using an inductive approach.

In this regard we were interested to develop for our study that approached fundamental research a network of core terms in order to develop complex theoretical frameworks that have the potential to summarize the core terms that are central to all researchers in our area of interest. This particular idea belongs to Papieneau (1979). His concept of hierarchy of core terms we considered to be useful for understand the development of a particular literature.

Even if his hierarchy is highly appreciate, in this area of research our study is the first one that apply his concepts based on our knowledge as we asserted before.

The importance of summarizing the internal body of the literature using Papineau's tree (1979) is indisputable since particular contributions can be identified easier and comprised in a well known framework in order to rationalize the existing literature.

For the segments comprised in our research that approached the conceptual delimitations we used as summarizing instrument the Papineau's approach (1980). When various studies were comprised in a segment of our research, treated in conjunction with various empirical references we 
approached the Hesse (1980) methodology in order to briefly present a large body of the literature, assuring in the same time the references to the most important developments that included novelty items over time. The rest of the scientific background approached is summarized using a classical view, highlighting what is important to be known when this area is approached and assessed.

The main idea of Papineau's (1979) was to develop according to what we stated before a hierarchy of core terms within a literature with the scope of identifying the particular contributions that can be placed and based on that, criticized. Four levels are discussed based on its methodology as the following:

Figure 1. Papineau's tree overview

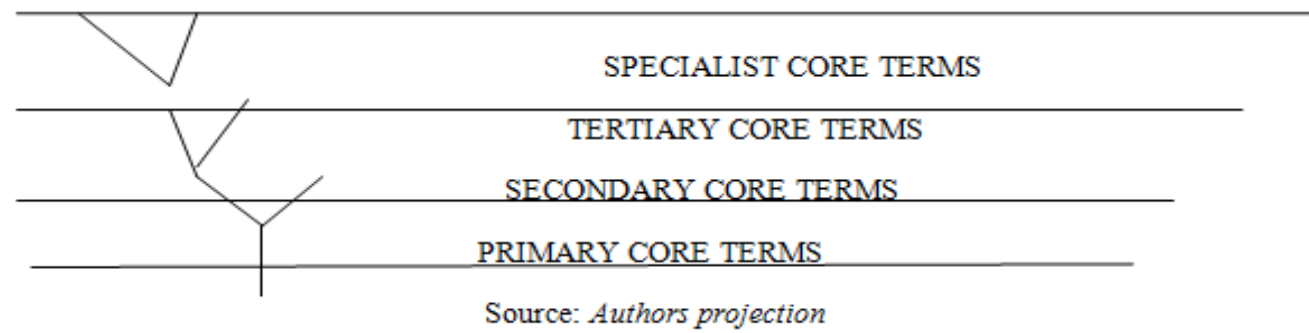

From examining the primary core terms for the concept True and Fair View we can assert that all of those constructions are used by all the researchers in this area of research while the fourth category of core terms comprise specialized terms, in which case we pointed out the term "overriding" and Saussure linguistic constructions "signifier" and "signified" that were highly discussed in association with True and Fair View since what it means and what it is perceived or believed that may mean are realities that create the perceptions gap discussed in the beginning of our study.

Since the area of our study regards true and fair view and creative accounting; those two concepts were examined under the above proposed methodology. In Table 1 we summarized the main findings after applying the above methodology, approaching primarily the concept of true and fair view.

Table 1. Conceptual delimitations regarding True and Fair View

\begin{tabular}{|c|c|c|c|c|}
\hline Scientific background & $\begin{array}{l}\text { Primary core } \\
\text { terms }\end{array}$ & $\begin{array}{l}\text { Secondary core } \\
\text { terms }\end{array}$ & $\begin{array}{l}\text { Tertiary core } \\
\text { terms }\end{array}$ & $\begin{array}{l}\text { Specialist core } \\
\text { terms }\end{array}$ \\
\hline $\begin{array}{l}\text { Saussure (1919), } \\
\text { Sir Russell Kettle (1984), } \\
\text { Burke (1964), } \\
\text { Cowan (1965), } \\
\text { Lee G.A. (1981), } \\
\text { Lee T.A. (1982) } \\
\text { Rutherford (1985, 1988), } \\
\text { Houghton (1987), } \\
\text { Chambers and Wolnizer } \\
\text { (1991), } \\
\text { Nobes and Parker (1991), } \\
\text { Walton (1991, 1993), } \\
\text { Fowle (1992), } \\
\text { Alexander (1993), } \\
\text { Arden (1993), } \\
\text { Hudack and Orsini (1993), } \\
\text { Higson and Blake (1993), } \\
\text { Burlaud (1993), } \\
\text { Ordelheide (1993, 1996), } \\
\text { Jones (1994), } \\
\text { Deegan et al. (1994), } \\
\text { Karan (2002), } \\
\text { McEnroe and Martens (2004), } \\
\text { Dean and Clarke (2005). }\end{array}$ & $\begin{array}{l}\text { Properly, } \\
\text { readily, } \\
\text { Objective, } \\
\text { Free from } \\
\text { bias, } \\
\text { Lack of } \\
\text { material facts, } \\
\text { Correspond to } \\
\text { economic } \\
\text { events, } \\
\text { Fair, } \\
\text { True, } \\
\text { Full and } \\
\text { proper, } \\
\text { Accurate and } \\
\text { correct, } \\
\text { Not } \\
\text { misleading, } \\
\text { Absence of } \\
\text { material error. }\end{array}$ & $\begin{array}{l}\text { Statutory } \\
\text { information, } \\
\text { Accurate figures, } \\
\text { Reasonable } \\
\text { estimates, } \\
\text { Without prejudice } \\
\text { to any particular } \\
\text { sectional interest, } \\
\text { Guide for auditors } \\
\text { and standard } \\
\text { setters, } \\
\text { Code expression for } \\
\text { GAAP, } \\
\text { Feature of financial } \\
\text { reporting. }\end{array}$ & $\begin{array}{l}\text { Essential } \\
\text { information, } \\
\text { Attitude of the } \\
\text { observer, } \\
\text { Susceptible to } \\
\text { vary, } \\
\text { Not to be deriving } \\
\text { from legal } \\
\text { meaning, } \\
\text { Formula for } \\
\text { international } \\
\text { disharmony, } \\
\text { Inappropriate } \\
\text { basis for } \\
\text { international } \\
\text { accounting } \\
\text { harmonization, } \\
\text { Legal residual } \\
\text { clause, } \\
\text { Black box. }\end{array}$ & $\begin{array}{l}\text { Signifier, } \\
\text { signified, } \\
\text { Overriding. }\end{array}$ \\
\hline
\end{tabular}

Source: Authors projection 
As it can be noticed the primary core terms include for the True and Fair View concept the most known similar assertions found in the literature. All of those are the assertions that were treated by all the researchers in conjunction with the concept approached.

The utility of this methodology consist in the fact that when researchers approach the examined area for the first time, by recurring to Papineau's tree he/she can identify rapidly the main concepts that share the view of almost all the previous researchers from this area. Also by examining the secondary terms to specialist core terms, one can identify the interest of different topic in the area and also the more specialized items that are approached in this respect.

Secondary core terms approached for true and fair view refers also to some similar assertions treated in the literature but not shared by the majority of researchers. A good example in this respect is the approach of Albu et al., (2009) "Guide for auditors and standard setters", similar assertion examined in our second empirical study concerning the perception of True and Fair View in the Romanian accounting environment. Other similar conceptual assertions can be consulted above.

Tertiary core terms include assertions that further explain True and Fair View through a spectrum of original views. Seen as "black box" or "Formula of disharmony", the assertions are approached only by a limited number of researchers. The number of researchers that are decreasing from the central core terms or primary to the specialist's core terms.

The following figure draws a theoretical framework that comprises the main items approached in the area of conceptual delimitations based on Papineau's tree methodology. By assessing the primary and secondary core terms we can develop the following conceptual framework as following:

Figure 2. Conceptual delimitation framework regarding True and Fair View

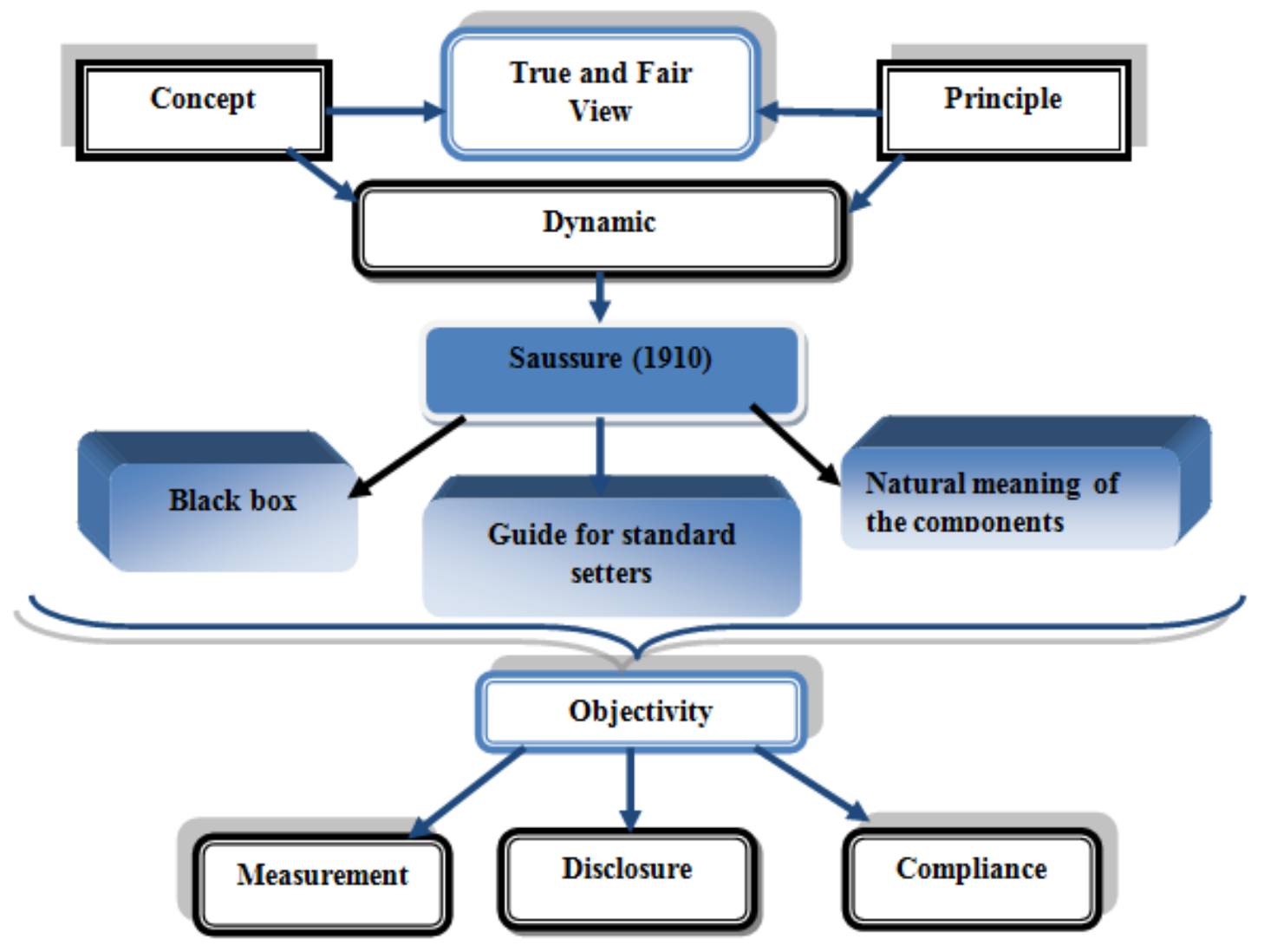

Source: Authors projection 
In the end, should be this concept or principle defined? Before anticipating any answer we should assert that defining as a principle involves general applicability and based on the debates assessed in the literature this could generate even more debate. The main feature of true and fair view is its dynamicity and that further is the base for its spectrum of debate regarding its meaning (e.g. Guide for standard setters, black box, natural meanings of its components). As a main conclusion when true and fair view is assessed, objectivity arises, comprising directions as: measurement, disclosure and compliance.

In Table 2, the main conceptual delimitations regarding Creative Accounting are presented based on Papineau's tree conceits (1979) as following:

Table 2. Conceptual delimitations regarding Creative accounting presented under all its forms of manifestations

\begin{tabular}{|c|c|c|c|c|}
\hline Scientific background & Primary core terms & $\begin{array}{l}\text { Secondary core } \\
\text { terms }\end{array}$ & Tertiary core terms & $\begin{array}{l}\text { Specialist } \\
\text { core terms }\end{array}$ \\
\hline $\begin{array}{l}\text { Beidleman (1973), } \\
\text { Barnea et al. (1976), } \\
\text { Metcalf (1977), } \\
\text { Koch (1981), } \\
\text { Jameson (1988), } \\
\text { Schipper (1989), } \\
\text { Watts and Zimmerman } \\
\text { (1990), } \\
\text { Naser (1993), } \\
\text { Bhat (1996), } \\
\text { Cormier and Magan } \\
\text { (1996), } \\
\text { Levitt (1998), } \\
\text { Healy and Wahlen (1999), } \\
\text { Brown (1999), } \\
\text { Bagnoli and Watts (2000), } \\
\text { Young (2000), } \\
\text { Dechow and Skinner } \\
\text { (2000), and Comiskey } \\
\text { Mulford and } \\
\text { (2002), } \\
\text { Goel and Thakor (2003), } \\
\text { Ortega and Grand (2003), } \\
\text { Phillips, Pincus and Rego } \\
\text { (2003), and Gowthorpe } \\
\text { Amat and } \\
\text { (2004), } \\
\text { Goncharov (2009) } \\
\text { Vladu and Matis (2010) } \\
\text { Jones (2011) }\end{array}$ & $\begin{array}{l}\text { Manipulation, } \\
\text { Cheating, } \\
\text { Misleading, } \\
\text { Omissions, } \\
\text { Smoothing, } \\
\text { Management actions, } \\
\text { Management } \\
\text { intention, } \\
\text { Accounting choice, } \\
\text { Accounting } \\
\text { principles, } \\
\text { Estimations, } \\
\text { Accounting rules, } \\
\text { Management } \\
\text { discretion, } \\
\text { Desired result, } \\
\text { Managenumbers, } \\
\text { Altering financial } \\
\text { reports, } \\
\text { Deliberate } \\
\text { manipulation, } \\
\text { Flexibility of } \\
\text { accounting } \\
\text { regulations, } \\
\text { Distort financial } \\
\text { performance, } \\
\text { Deceiving exercise, } \\
\text { Deceptive } \\
\text { accounting, } \\
\text { Transformation of } \\
\text { accounting figures. }\end{array}$ & $\begin{array}{l}\text { Reporting } \\
\text { aggressiveness, } \\
\text { Eamings } \\
\text { manipulation, } \\
\text { Ambiguity of } \\
\text { accounting rules, } \\
\text { Reduce abnormal } \\
\text { variations in } \\
\text { eamings, } \\
\text { Overstate net } \\
\text { income, } \\
\text { The view of } \\
\text { reality. }\end{array}$ & $\begin{array}{l}\text { Real earnings } \\
\text { management, } \\
\text { Disclosure } \\
\text { management, } \\
\text { Lack of neutral } \\
\text { operation, } \\
\text { Timing operating } \\
\text { decisions, } \\
\text { Mislead, } \\
\text { Improper earnings } \\
\text { management, } \\
\text { Lack of creating } \\
\text { value, } \\
\text { Mark of skill and } \\
\text { excellence, } \\
\text { Creativity. }\end{array}$ & \\
\hline
\end{tabular}

Source: Authors projection

As it can be noticed the main items comprised for creative accounting concept in the primary core terms (that share the highest level of consensus) are related to manipulation, misleading, management discretion and flexibility of accounting, all being defined are an aura of negative tenure. The creativity item, that is approached in the literature and based on it, creative accounting, is defined, is included in the tertiary core items level, being shared by a limited number of researchers. Based on those results other research question arises: Is the term creative accounting proper as terminology for the area approached or manipulative accounting or further misleading accounting is more adequate?

We couldn't identify any specialist terms. 


\section{Conclusions, limitation and scope for future research}

When it comes to True and Fair View we can assert that the concept does not have a generally accepted definition, only a noticeable trend that try to compare it with the American "present fairly" and to conclude that both concepts have one and the same meaning. It is considered that True and Fair View requirement is a legal concept, even if no definition of it has been elaborated by the legislators. In this respect our view is similar to Alexander (1993) view.

Since few definitions of true and fair view concept were developed so far we intend to contribute to knowledge by presenting our view regarding what this concept might mean. In this respect we consider that the principle of True and Fair View is an expression of flexibility in order to derogate from a mechanical application of the law and further uses professional judgment in order to reflect economic reality through the language of accounting with the utmost circumspection.

Since our research was a fundamental one, we took into account the opinion of Ryan et al. (1993) and used a methodology that is suitable for our scientific demarche (e.g. Papieau's three). The main advantage of using Papineau's tree (1979) in the arena of creative accounting consisted in this regard in answering on one of the main debated items in this area regarding the definition of creative accounting that must comprise primarily creativity or manipulation.

As we can observe from the above, by applying the methodology approached, the central core terms for creative accounting are all related to MANIPULATION not creativity. The creativity appears approached in tertiary core terms suggesting that only few researchers approach and describes creative accounting based on its novelty. Even if the reference to creativity is approached sporadically in the literature, the terminology includes this term. In this respect we ask rhetorical, is creative accounting as terminology suitable or not? If not, which terminology can comprise better the areas features?

We accept the creativity component in the area approach but as we stated before, this component represent only a small part of the area approached, even if is the most important one since is the one that is the hardest to detect. If based on Papineau's methodology, true and fair view concept can be easily assessed, creative accounting brings into attention even more debate. Further research will be needed in order to assess empirically what is prevailing in the area approaches: creativity or manipulation? If manipulation is the main feature assessed empirically, creativity should define this whole area?

Since this study aim to be an interpreter of the literature, the sampling of the literature was crucial. Since we used only the sources that were written in English language this could result in a important limitation of the study.

\section{Acknowlegment}

* Investing in people! PhD scholarship, Project co-financed by the European Social Fund, SECTORAL OPERATIONAL PROGRAMME HUMAN RESOURCES DEVELOPMENT 2007 2013, Babeş-Bolyai University, Cluj-Napoca, Romania

\section{References}

1. Alexander D., 1993. A European True and Fair View?, European Accounting Review, Vol. 2, No. 1, pp. 59-80

2. Amat S.O., Gowthorpe C., 2004. Creative Accounting: Nature, Incidence and Ethical Issues, Working Paper Series, Universitat Pompeu Fabra, no. 749, available at SSRN: http://papers.ssrn.com/sol3/papers.cfm?abstract_id=563364, consulted at 21.11.2009

3. Barnea A., Ronen J., Sadan S., 1976. Classificatory Smoothing of Income with Extraordinary Items, The Accounting Review (January), pp. 110-122 
4. Bagnoli M., Watts S., 2000. The effect of relative performance evaluation on earnings management: a game-theoretic approach, Journal of Accounting and Public Policy, vol. 19, available on SSRN: http://papers.ssrn.com /sol3/papers.cfm?abstract_id=253966, consulted at 23.03.2010

5. Beidleman C.R., 1976. Income Smoothing: The Role of Management, The Accounting Review, vol. 48, no. 4, pp. 653-667

6. Bhat V.N., 1996. Banks and Income Smoothing: An Empirical Analysis, Applied Financial Economics, vol. 6, pp. 505-510

7. Brown P., 1999. Earnings management: A subtle (and troublesome) twist to earnings quality, Journal of Financial Statement Analysis, Winter

8. Burlaud A., 1993. Commentary on "A European true and fair view", European Accounting Review, vol. 2, issue 1, pp. 95-98

9. Chambers R.J., 1973. Accounting Principles and the Law, Australian Business Law Review, vol. 1 , no. 2

10. Cormier D., Magnan M., 1996. Decisions, decisions, CA Magazine, September

11. Cowan T.K., 1965. Are Truth and Fairness Generally Acceptable? The Accounting Review, vol. 40 , no. 4 , pp. $788-794$

12. Dean G., Clarke F., 2005. "True and Fair" and "Fair Value" - Accounting and Legal Willo'-the-Wisps', Abacus, vol. 41, no. 2, pp. i-vi

13. Deegan C., Kent P., Lin C.J., 1994. The True and Fair View: A Study of Australian Auditors' Application of the Concept, Australian Accounting Review, vol. 4, no. 1

14. Dechow P.M., Skinner D., 2000. Earnings Management: Reconciling the Views of Accounting Academics, Practitioners, and Regulators, Accounting Horizons, June, pp. 235250

15. Edey H., 1971. The true and fair view, Accountancy, vol. 82 (August), pp. 440-441

16. Fowle M., 1992. True and fair - or only fairly true?, Accountancy, vol. 109 (June), pp.1-29

17. Gearin M., Khandelwal S., 1995. A true and fair view or mandatory standards?, Australian Accountant, vol. 65, pp. 12-16

18. Goel A., Thakor A., 2003. Why do firms smooth earnings?, Journal of Business, vol. 76, no. 1, pp. 151-192

19. Goncharov I., 2009. Does Reporting Timeliness Affect Book-Tax Differences?, Working Paper, Amsterdam Business School, University of Amsterdam, available at: http://www.gsom.pu.ru/files/upload/niim/seminar/timeliness_and_book tax differences.pdf, consulted at: 21.06 .2010

20. Healy P., Wahlen J., 1999. A Review of the Earnings Management Literature and its Implications for Standard Setting, Accounting Horizons, vol.13, no. 4, pp. 365-383

21. Hoffman L., Arden M., 1983. Legal opinion on "true and fair view", Accountancy, vol. 94, pp. 154-156

22. Hudack L.R., Orsini L.L., 1993. A review of the implementation of "true and fair" financial reporting in France from a socio-historical perspective, International Accounting Auditing and Taxation, vol. 2, no. 2, pp. 197-213

23. Jameson M., 1988. A Practical Guide to Creative Accounting, Kogan Page, London, pp. 2021

24. Jones M., 1994. Readability of accounting narratives, Management Accounting, vol. 72 (April), pp. 1-28

25. Jones M., 2011. Creative accounting, Fraud and International Accounting Scandals, John Wiley and Sons Ltd, London

26. Karan R., 2002. Irreconcilable legal and accounting views of 'a true and fair view'. An emerging alternative from Australian reforms, Journal of Law and Financial Management, vol. 1 , no. 1 , pp. $44-52$ 
27. Koch B.S., 1981. Income Smoothing: An Experiment, The Accounting Review, vol. 56, no. 3, pp. 574-586

28. Leach R., Newsom P., 2007. Do Firms Manage their Earnings Prior to Filing to Bankruptcy, Academy of Accounting and Financial Studies Journal, vol. 11, no. 3, pp. 125-137

29. Levitt A., 1998. The Numbers Game, Remarks at the NYU Center for Law and Business, September 28, Speech available at: http://www.sec.gov/news/speech /speecharchive/1998/spch220.txt

30. McBarnet D., Whelan C., 1999. Creative Accounting and the Cross-Eyed Javelin Thrower, John Wiley and Sons, Ltd., London, pp. 102

31. Metcalf L., 1977. The Accounting Establishment, Staff study as the Chairman of the US Senate Subcommittee, The United States Government Printing Office, Washington, D.C., pp. 188

32. Mulford C.W., Comiskey E.E., 2002. The financial numbers game: detecting creative accounting practices, Wiley, New York

33. Naser K., 1993. Creative financial accounting: its nature and use, Prentice Hall, Hemel Hempstead, pp. 2, pp. 9

34. Nobes C.W., Parker R.H., 1991a. True and Fair: UK Auditors' View, Accounting and Business Research, vol. 84 (Autumn), pp. 349-361

35. Nobes C.W., Parker R.H., 1991b. True and fair: a survey of UK financial directors, Journal of Business Finance and Accounting, vol. 18, pp. 359-375

36. Nobes C.W., 1993. The true and fair view requirement: impact on and of the Fourth Directive, Accounting and Business Research, vol. 24, no. 93, pp. 35-47

37. Ordelheide D., 1993. True and fair view: a European and German perspective, European Accounting Review, vol. 2, issue 1, pp. 81-90

38. Ordelheide D., 1996. True and fair view: A European and a German perspective II, The European Accounting Review, vol. 5, issue 3, pp. 495-506

39. Ortega W.R., Grant G.H., 2003. Maynard manufacturing: an analysis of GAAP-based and operational earnings management techniques, Strategic Finance, July, pp. 50-56

40. Parker R.H., Nobes C.W., 1994. What they say about true and fair: a survey of the Englishlanguage literature, in Parker R.H. and Nobes C.W. (eds.), An International View of True and Fair, Routledge, London, pp. xiii

41. Phillips J., Pincus M., Rego S.O., 2004. Decomposing changes in deferred tax assets and liabilities to isolate earnings management activities, The Journal of the American Taxation Association, vol. 26, pp. 43-66

42. Pound G., 1985. The "true and fair" debate - accounting bodies reply, Chartered Accountant in Australia, vol. 56, pp. 28-31

43. Radcliffe G.W., 1990. Accounting standards and the judiciary, Accounting and Business Research, vol. 20, pp. 329-336

44. Rutherford B.A., 1985. The True and Fair Doctrine: A Search for Explication, Journal of Business Finance and Accounting, vol. 12, no. 4, pp. 483-494

45. Ryan B., Scapens R.W., Theobald M., 1993. Research Method and Methodology in Finance and Accounting, Academic Press Limited, London, pp. 153-154

46. Schipper K., 1989. A commentary on earnings management, Accounting Horizons, vol. 3, no. 4, pp. 91-102

47. Schipper K., 2000. Accounting Research and the Potential use of International Accounting Standards for Cross-Border Securities Listings, The British Accounting Review, vol. 32, pp. 243-256

48. Vladu A.B., Matis D., 2010. Corporate Governance And Creative Accounting: Two Concepts Strongly Connected? Some Interesting Insights Highlighted By Constructing The Internal History Of A Literature, Annales Universitatis Apulensis Series Oeconomica, pp. 
332-346, indexat REPEC, indexat REPEC, Available at: http://oeconomica.uab.ro/upload/ 1220101/33.pdf

49. Walton P., 1993. Introduction: The True and Fair View in British Accounting, European Accounting Review, vol. 1, pp. 49-58

50. Watts R.L., Zimmerman J.L., 1990. Positive accounting theory: a ten year perspective, The Accounting Review, vol. 65, pp. 131-156

51. Young M.R., 2000. Accounting Irregularities and Financial Fraud: A Corporate Governance Guide, pp. 13 